\title{
Strategi Pendidikan Agama Islam Dalam Meningkatkan Kualitas Kepribadian Siswa Di MTs Negeri Probolinggo
}

\begin{abstract}
Abdul Hamid ${ }^{*}$
Abstract. Education has always sought to provide guidance to students to establish and develop science and personality intact. The importance of improving the quality of education for students, and based on the term that education is as one program that can prepare and predict the development of students in the future, then, some efforts should be made by the Islamic educational institutions. In this case, MTs Probolinggo is one that should be oriented to achieve the quality of personality to development and prepare future generations who are ready to face the globalization era. In achieving this goal, the Islamic religious education in particular must have the correct strategy and precise in its development.

Based on the reality happened in MTs Probolinggo, the learning of Islamic religious education in schools had been running in precise. But Islamic religious education especially MTs Probolinggo this should be taken to ensure that students not only can learn by heart religious lessons, but also able to be affective and behavioral. It is evident that in the previous year students MTs Probolinggo one has a moral decline that is one of the students exposed to cases of liquor. But it can be solved by getting serious handlers by the school so that the good name of MTs Probolinggo back brilliantly.

From the background of the above problems, the researcher is motivated to conduct the research on the strategy of Islamic religious education in improving students' personalities in MTs Probolinggo. The focal points of this study are: (1) how is the steps of learning Islamic religious education in improving the quality of students' personalities in MTs Probolinggo?; (2) how is the implementation of learning Islamic religious education in students personality development in MTs Probolinggo?.

The objectives in this study are: (1) to describe the steps of learning Islamic religious education in improving the quality of students' personalities in MTs Probolinggo; (2) to describe the implementation of learning Islamic education in improving the quality of students' personalities in MTs Probolinggo.

Based on the data obtained and the result of this research, it can be can be summarized as follows: The first steps of learning Islamic education in improving the quality of students' personalities in the MTs Probolinggo can be quite good. Teachers of Islamic religious education in MTs Probolinggo has taken steps learning through teacher's council of Islamic religious education lessons, ranging from the preparation of the appropriate standard of syllabus content,
\end{abstract}

* Dosen tetap Institut Ilmu keislaman Zainul hasan Genggong Kraksaan Probolinggo 
standard competence and guide the preparation curriculum KTSP; make analysis today effective; effective last analysis; annual program; term program and lesson plan.

Keywords: Islamic education strategy, Improving the quality of student personality

\section{A. Pendahuluan}

Pendidikan dapat dikatakan sebagai wujud proses yang dapat membantu pertumbuhan seluruh unsur kpribadian manusia secara seimbang ke arah yang positif. Sebagaimana Ki Hajar Dewantara dalam Binti Maunah mengungkapkan bahwa "pendidikan yaitu tuntunan di dalam hidup tumbuhnya anak-anak, adapun maksudnya pendidikan yaitu menuntun segala kekuatan kodrat yang ada pada anak-anak agar mereka sebagai manusia dan sebagai anggota masyarakat dapat mencapai keselamatan dan kebahagiaan yang setinggi-tingginya".

Kemudian dalam Undang Undang RI No. 20 Tahun 2003 tentang Sistem Pendidikan Nasional disebutkan bahwa:

Pendidikan adalah usaha sadar dan terencana untuk mewujudkan suasana belajar dan proses pembelajaran agar peserta didik secara aktif mengembangkan potensi dirinya untuk memiliki kekuatan spiritual keagamaan, pengembalian diri, kepribadian, kecerdasan, akhlak mulia, serta keterampilan yang diperlukan dirinya, masyarakat, bangsa dan negara (Sisdiknas, 2011:3).

Pendidikan menjadi ujung tombak maju mundurnya suatu bangsa. Ketika bangsa mempunyai kualitas pendidikan yang baik, maka proses pembangunan menjadi baik pula berkembangnya. Karena melalui proses pendidikan manusia dengan segala potensi yang dimiliki akan tumbuh dan berkembang sesuai dengan tuntutan dan perubahan zaman.

Adapun tujuan pendidikan di Indonesia sebagaimana tertulis dalam UndangUndang RI No. 20 Tahun 2003 tentang Sistem Pendidikan Nasional yang berbunyi:

Pendidikan nasional berfungsi mengembangkan kemampuan dan membentuk watak serta peradaban bangsa yang bermartabat dalam rangka mencerdaskan kehidupan bangsa, bertujuan untuk berkembangnya potensi peserta didik agar mnejadi manusia yang beriman bertaqwa kepada kepada Tuhan yang maha Esa, berakhlak mulia, sehat, berilmu, cakap, kreatif, mandiri, dan menjadi warga negara yang demokratis serta bertanggung jawab (Sisdiknas, 2011: 7).

Untuk itu maka pendidikan agama Islam harus memandang bahwa siswa bukanlah hanya sebagai botol kosong yang harus dijejali dengan ilmu pengetahuan yang sebanyak-banyaknya, melainkan "lampu" yang harus 
dinyalakan (dikembangkan potensinya). Karena pada dasarnya, Islam sangat menghargai dan mendorong Ummatnya untuk berfikir kritis dan kreatif.

Sebagaimana yang diungkapkan oleh Syamsul Ma'arif (2007: 74) yang menyatakan bahwa "fungsi pendidikan tidak sekadar sebagai 'agent of knowledge' akan tetapi harus mampu mengakomodir pengalaman, keterampilan dan nilai-nilai globalisasi dalam satu paket pendidikan”.

Jadi titik sentral yang menjadi kunci berhasil atau tidaknya suatu bangsa dalam membangun negaranya, tergantung dengan kualitas manusianya, yakni peserta didik khususnya yang akan menjadi penerus bangsa. Peneliti berpandangan bahwa Islam, khususnya di Indonesia bisa bangkit, dengan Muslim yang kuat dan berkualitas jika memiliki tiga faktor yang telah terpenuhi, yaitu "iman, ilmu, dan amal shaleh" atau perbuatan produktif yang menjadi indikator tinggi rendahnya kualitas kepribadian siswa.

Dalam upaya meningkatkan kehidupan masyarakat pada taraf yang lebih baik dan bisa berkembang secara dinamis, pendidikan mempunyai peranan yang urgen untuk mewujudkan hal tersebut. Dalam hal ini pendidikan merupakan usaha untuk memberikan bimbingan kepada siswa dalam rangka untuk membentuk karakter, pengembangan pengetahuan dan kepribadian secara utuh, mampu bertanggung jawab terhadap segala perbuatannya serta dapat memenuhi fungsi hidupnya baik jasmaniah maupun rohaniah. Dengan demikian pendidikan merupakan usaha yang fundamental dalam kehidupan masyarakat.

Sehubungan dengan hal tersebut, pendidikan dalam Islam mempunyai peranan yang amat penting dalam rangka mentransformasikan nilai-nilai yang ada di dalam ajaran agama Islam. Sehingga nilai-nilai yang ada dapat terealisasikan dalam kehidupan sehari-hari, sebagaimana yang telah dikemukakan oleh Muzayyin Arifin yaitu' ${ }^{1}$

Peranan pendidikan agama Islam merupakan salah satu bentuk manefestasi dari cita-cita hidup untuk melestarikan, mengalihkan, menanamkan, serta mentrasformasikan nilai-nilai Islam tersebut kepada generasi penerusnya, sehingga nilai-nilai kultural-relegius yang dicitacitakan dapat tetap berfungsi dan berkembang dalam kehidupan masyarakat.

Agama Islam memandang bahwa pendidikan merupakan sesuatu yang esensial dalam memberikan predikat baik buruknya perjalanan hidup seseorang. Maka sudah sepantasnya, jika Islam mewajibkan untuk menuntut ilmu bagi setiap Ummatnya. Hal ini untuk memberikan pembinaan kualitas kepribadian terhadap siswanya, yaitu pribadi yang mandiri mantap, serta tangguh dalam

\footnotetext{
${ }^{1}$ Arifin, Muzayyin, 2000. Filsafat Pendidikan Islam. Jakarta: Bumi Aksara. Hal: 11.
} 
memperjuangkan kehidupannya berdasarkan nilai-nilai yang terkandung dalam ajaran agama Islam.

Dengan memperhatikan pentingnya pendidikan bagi peningkatan kualitas siswa, serta melihat pendidikan merupakan salah satu program yang dapat menyiapkan dan merekayasa arah perkembangan siswa di masa depan, maka berbagai upaya perlu dilakukan oleh lembaga pendidikan Islam, dalam hal ini MTs Negeri Probolinggo yang harus berorientasi untuk mewujudkan kualitas kepribadian siswa serta mempersiapkan generasi-generasi yang siap menghadapi era globalisasi. Untuk keperluan ini pendidikan harus sanggup bersaing dalam era globalisasi dengan mementingkan visi, efisiensi, daya kreatifitas dan pandangan yang kritikal.

Dalam hal ini peneliti berpandangan bahwa kiblat Ummat Islam bukanlah dunia Barat, melainkan pendidikan agama Islam yang harus disandarkan kepada telaah folosofis antroplogis, yang menjadikan Al-Qur'an, Al-Hadis, Ijma' dan Qiyas sebagai dasarnya. Hal ini dengan pertimbangan, karena melihat situasi dan kondisi sosiologis yang sedang mengalami pergeseran nilai pada setiap ruas dan sendi kehidupan manusia, termasuk nilai-nilai budaya yang mulai tercabut dari akarnya.

Nilai sosial yang banyak terilhami oleh rembesan pergaulan bebas dari dunia Barat melalui berbagai tindakan dan pergeseran nilai-nilai kemanusiaan yang lain. Intinya, pendidikan agama Islam harus merujuk kembali kepada permata yang hilang (heritage in the golden age) merekonstruksi dan mereformulasikannya sebagai konsep pendidikan agama Islam yang siap mengantisipasi dan menyikapi perubahan zaman dengan kualitas siswa yang memadai.

Perkembangan ilmu pengetahuan dan teknologi (IPTEK) yang semakin pesat tidak hanya mendatangkan dampak yang positif bagi manusia, tetapi juga memiliki dampak yang negatif, yakni dengan semakin banyaknya tingkah laku anak yang menyimpang dari norma-norma agama. Oleh karena itu menjadi tanggung jawab orang tua dan lembaga pendidikan untuk mengatasinya. Lebihlebih pada lembaga pendidikan agama Islam. Salah satu antisipasi yang dapat dilakukan adalah dengan memberikan pembinaan kepribadian yang tepat kepada siswa secara kontinu melalui internalisasi nilai-nilai pendidikan Islam.

Pendidikan agama Islam mempunyai peranan yang urgen dalam pembinaan kualitas kepribadian siswa serta menanamkan budi pekerti yang luhur sebagai manefestasi dari pembangunan manusia seutuhnya. Ummat Islam seharusnya senantiasa mengadakan perbaikan secara dinamis dalam segala aspek kehidupan. Salah satu sarana efektif untuk membina dan mengadakan perbaikan dalam kehidupan masyarakat adalah melalui pendidikan yang betul-betul memiliki strategi yang tepat dalam meningkatkan kualitas kepribadian siswa. 
Pemilihan strategi yang tepat dalam mengembangkan kualitas pendidikan merupakan salah satu upaya pemerintah untuk mencapai keunggulan masyarakat dan bangsa dalam penguatan ilmu dan teknologi yang ditunjukkan dengan pernyataan politik dalam Garis-Garis Besar Haluan Negara. (Mulyasa, 2002:11)

Pada realitas yang terjadi di MTs Negeri Probolinggo bahwa pembelajaran pendidikan agama Islam dalam hal meningkatkan kulaitas kepribadian siswa yang selama ini berjalan di madrasah sudah cukup optimal, namun pendidikan agama Islam khususnya di MTs Negeri Probolinggo ini harus lebih diperhatikan agar siswa tidak hanya bisa mengahafalkan pelajaran-pelajaran agama, tetapi juga mampu secara afektif dan behavioral.

Hal ini terbukti bahwa pada tahun sebelumnya siswa MTs Negeri Probolinggo telah mengalami kemerosotan moral yaitu salah satu siswanya terkena kasus minuman keras. Namun hal itu dapat diatasi karena mendapatkan penangan yang serius oleh sekolah sehingga nama baik MTs Negeri Probolinggo kembali cemerlang.

Ini menandakan bahwa sesuatu yang diharapkan di sini tidak sekedar pada tuntutan kompetensi, tetapi juga bagaimana ke depan mereka bisa diprediksi dalam memahami dan memaknai agamanya. Secara intelektual siswa mengetahui nilai-nilai ajaran agamanya tetapi perilakunya tidak relevan dengan nilai-nilai ajaran agama yang diketahuinya.

Pendidikan agama Islam sebagaimana yang dicita-citakan secara nasional, barangkali dalam konteks era sekarang ini menjadi tidak menentu, atau kabur mengingat adanya tuntutan pola kehidupan pragmatis dalam masyarakat Indonesia. Hal ini patut untuk dikritisi bahwa globalisasi bukan semata mendatangkan efek positif, dengan kemudahan-kemudahan yang ada, akan tetapi, berbagai tuntutan kehidupan yang disebabkan olehnya menjadikan terjadinya disorientasi pendidikan. Pendidikan cenderung berpijak pada kebutuhan pragmatis, atau kebutuhan pasar, lapangan kerja sehingga ruh pendidikan sebagai pondasi budaya, moralitas, dan social movement (gerakan sosial) menjadi hilang.

Pendidikan agama Islam harus bisa mengejawantahkan nilai-nilai ajaran agama Islam dalam kehidupan sehari-hari, kapan dan di manapun. Pendidikan agama Islam harus menjadi sebuah spirit untuk meraih kehidupan yang lebih baik dan layak di dunia, dan juga harus menjadi pengontrol segala tindakan manusia agar dalam meraih tujuan hidup yang layak tersebut tetap dengan memegang teguh nilai-nilai ajaran agama Islam.

Strategi merupakan sebuah komponen yang sangat berpengaruh dalam dunia pendidikan, terlebih pada proses pembelajaran pendidikan agama Islam. Strategi pembelajaran pendidikan agama Islam ini merupakan salah satu upaya untuk menerapakan bagaimana nilai-nilai ajaran agama Islam yang ada pada tiap materi mampu diserap, dihayati serta bisa diamalkan oleh peserta didik. 
Dengan adanya strategi yang tepat dalam pendidikan agama Islam di lembaga pendidikan, terutama lembaga pendidikan Islam dalam hal ini MTs Negeri Probolinggo, diharapkan akan mampu menghasilkan output yang memiliki kualitas kepribadian yang luhur dan mengamalkan nilai-nilai ajaran agama Islam dalam kehidupan mereka.

Kompleksnya persoalan pendidikan disatu sisi dan tuntutan meningkatkan kualitas kepribadian siswa disisi lain menyebabkan persoalan pendidikan tetap menarik untuk dibahas dengan harapan pembahasan ini mampu memunculkan solusi alternatif dalam mengembangkan kualitas kepribadian siswa melalui jalur pendidikan agama Islam.

Dari beberapa fenomena dan alasan inilah, muncul ide perlu adanya penelitian tentang "Strategi pendidikan agama Islam dalam meningkatkan kualitas kepribadian siswa di MTs Negeri Probolinggo", dengan harapan dapat mengetahui lebih jauh bagaimana langkah-langkah strategi pembelajaran pendidikan agama Islam dan implementasi strategi pembelajaran pendidikan agama Islam dalam meningkatkan kualitas kepribadian siswa.

Berdasarkan uraian teori di atas, permasalahan yang diteliti dalam penelitian ini adalah bagaimana langkah-langkah strategi pembelajaran pendidikan agama Islam dalam meningkatkan kualitas kepribadian siswa di MTs Negeri Probolinggo? dan bagaimana implementasi strategi pembelajaran pendidikan agama Islam dalam meningkatkan kualitas kepribadian siswa di MTs Negeri Probolinggo?

Melalui penelitian ini diharapkan dapat diketahui tentang langkah-langkah pembelajaran pendidikan agama Islam dalam meningkatkan kualitas kepribadian siswa di MTs Negeri Probolinggo. Dan implementasi pembelajaran pendidikan agama Islam dalam meningkatkan kualitas kepribadian siswa di MTs Negeri Probolinggo.

\section{B. Pembahasan}

\section{Langkah-langkah Pembelajaran Pendidikan Agama Islam Dalam Meningkatkan Kualitas Kepribadian Siswa Di MTs Negeri Probolinggo}

Langkah-langkah strategi pembelajaran adalah menyusun langkah-langkah yang akan dilaksanakan untuk mencapai tujuan yang ditentukan dalam pembelajaran. Langkah-langkah pembelajaran tersebut dapat disusun berdasarkan kebutuhan dalam jangka waktu tertentu sesuai dengan keinginan. Namun yang lebih utama adalah langkah-langkah pembelajaran yang dibuat 
harus dapat dilaksanakan dengan mudah dan tepat sasaran. ${ }^{2}$

Dalam konteks pembelajaran, langkah-langkah dapat diartikan sebagai proses penyusunan materi, pembelajaran, penggunaan media pengajaran, penggunaan pendekatan dan metode pembelajaran, penilaian dalam suatua lokasi waktu yang akan dilaksanakan pada masa tertentu untuk mencapai tujuan yang telah ditentukan.

Aktivitas pembelajaran pendidikan agama Islam merupakan salah satu mata pelajaran di sekolah yang syarat sekali dengan muatan nilai kehidupan Islami, perlu diupayakan melalui langkah-langkah pembelajaran yang baik, agar mempengaruhi pilihan, putusan dan pengembangan kehidupan siswa. Oleh karena itu salah satu kemampuan yang harus dimiliki oleh guru pendidikan agama Islma adalah membuat langkah-langkah pembelajaran secara profesional dalam melaksanakan tugas dan tanggungjawabnya sebagai seorang pendidik, pembelajar, dan sekaligus sebagai perancang pembelajaran.

Melihat pentingnya sebuah perencanaan dalam kegiatan pembelajaran, maka seorang guru harus membuat langkah-langkah pembelajaran sebelum melaksanakan kegiatan pembelajaran. Pembuatan langkah-langkah pembelajaran harus mengacu pada silabus, karena silabus merupakan sumber pokok dalam langkah-langkah pembelajaran, baik langkah-langkah pembelajaran untuk satu standar kompetensi maupun satu kompetensi dasar.

Langkah-langkah pembelajaran merupakan suatu kegiatan yang dilakukan agar kegiatan belajar mengajar dapat berjalan dengan baik, disertai dengan berbagai langkah yang antisipatif guna memperkecil kesenjangan yang terjadi sehingga kegiatan tersebut mencapai tujuan yang ditetapkan.

Berdasarkan data lapangan menunjukkan bahwa dalam menentukan langkah-langkah pembelajaran pendidikan agama Islam di MTs Negeri Probolinggo secara keseluruhan berada dibawah tanggung jawab tim Musyawarah Guru Mata Pelajaran (MGMP) yaitu terhadap bapak Zaenol Hasan selaku waka kurikulum dan bapak Ach. Ramli selaku koordinator guru pendidikan agama Islam dan kepala sekolah sebagai penanggung jawab dan tim ini melakukan koordinasi bulanan dan akan membuat kebijakan baru disetiap akhir semester untuk melakukan perbaikan dan penyempurnaan dalam proses pembelajaran guna meningkatkan kualitas kepribadian siswa.

Dengan adanya koordinator guru pendidikan agama Islam atau Musyawarah Guru Mata Pelajaran (MGMP) diharapkan mampu untuk memeberikan motivasi yang tinggi terhadap guru-guru pendidikan agama Islam di MTs Negeri 1 Probolinggo untuk memberikan pelayanan yang baik

2 Abdul Majid. 2007. Perencanaan Pembelajaran Mengembangkan Standar Kompetensi Guru. Bandung. Hal: 17 
terhadap siswa guna mengefektifkan, mengefisienkan, serta mengoptimalkan fungsi dan interaksi antara siswa dengan komponen pembelajaran dalam suatu kegitan pembelajaran untuk mencapai tujuan pembelajaran.

Ini menunjukkan bahwa langkah-langkah pembelajaran pendidikan agama Islam di MTs Negeri Probolinggo betul-betul sudah terkoordinir dengan baik. Dan hal ini sesuai dengan Peraturan Menteri Pendidikan Nasional Republik Indonesia Nomor 19 Tahun 2007 Tentang Standart Pengelolaan Pendidikan oleh Satuan Pendidikan Dasar dan Menengah yang berbunyi: "Dalam penyusunan langkah-langkah pembelajaran dan silabus, guru dapat bekerjasama dengan Kelompok Kerja Guru (KKG), Musyawarah Guru Mata Pelajaran (MGMP), lembaga Penjamin Mutu Pendidikan (LPMP), atau Perguruan Tinggi”. (Sisdiknas, 2011: 193)

Dari hasil lapangan menunjukkan bahwa langkah-langkah pembelajaran pendidikan agama Islam di MTs Negeri Probolinggo 1 bisa dikatakan cukup baik. Kaitannya dengan hal yang diteliti dalam penelitian ini, para guru khususnya guru bidang studi pendidikan agama Islam di MTs Negeri Probolinggo telah melakukan langkah-langkah pembelajaran melalui Musyawarah Guru Mata Pelajaran pendidikan agama Islam (MGMP), mulai dari hal penyusunan silabus yang sesuai standart isi, standart kompetensi lulusan dan panduan penyusunan KTSP serta penyusunan rencana pelaksanaan pembelajaran (RPP).

Berdasarkan hasil lapangan di atas dapat interpretasikan bahwa seorang guru memiliki tanggung jawab untuk menyusun silabus dan perangkat lain yang berkaitan dengan pembelajaran, sebagaimana dalam Peraturan Menteri Pendidikan Nasional Republik Indonesia Nomor 19 Tahun 2007 Tentang Standart Pengelolaan Pendidikan oleh Satuan Pendidikan Dasar dan Menengah yang berbunyi: "Setiap guru bertanggung jawab menyusun silabus sesuai standart isi, standart kompetensi lulusan dan panduan penyusunan KTSP.” (Sisdiknas, 2011: 192)

Adapun langkah-langkah pembelajaran yang dilakukan oleh guru di di MTs Negeri Probolinggo adalah membuat langkah-langkah pembelajaran yang berisi: standart kompetensi, kompetensi dasar yang ingin dicapai, indikator, tujuan pembelajaran, sumber belajar, metode pembelajaran, skenario pembelajaran dan penilaian.

Sesuai dengan temuan di lapangan menunjukkan bahwa langkah-langkah yang dilakukan dalam pembelajaran pendidikan agama Islam di MTs Negeri Probolinggo ini dalam meningkatkan kualitas kepribadian siswa yaitu setelah membuat analisis hari efektif, analisis pekan efektif, program tahunan, program semester dan silabus. Langkah selanjutnya membuat rencana pelaksanaan pembelajaran (RPP) yang memuat 3 unsur kegiatan yaitu 
kegiatan pendahuluan atau awal, kegiatan inti dan kegiatan penutup.

Dalam kegiatan awal guru mengkondisikan siswa pada kesiapan menerima pelajaran berupa pemberian motivasi belajar dan upaya untuk memfokuskan siswa pada pelajaran yang akan disampaikan. Dalam kegiatan inti penyampaian materi pelajaran oleh guru dengan menggunakan pendekatan dan metode yang sesuai, tetapi metode yang sering digunakan adalah metode ceramah, tanya jawab, demonstrasi, dan diskusi. Kemudian kegiatan penutup penyampaian kesimpulan dari apa yang telah dipelajari siswa.

Jika dihubungkan dengan teori ternyata masih ada relevansi, sebagaimana secara teori dinyatakan bahwa dalam langkah-langkah pembelajaran ada tiga langkah pokok yang harus diperhatikan dan diterapkan yaitu sebagai berikut:

a. Tahap permulaan (pra instruksional), adalah tahapan persiapan guru sebelum kegiatan pembelajaran dimulai.

Dalam tahapan ini kegiatan yang dapat dilakukan guru, antara lain:

1) Memeriksa kehadiran siswa

2) Pretest (menanyakan materi sebelumnya)

3) Appersepsi (mengulas kembali secara singkat materi sebelumnya)

b. Tahap pengajaran (instruksional), yaitu langkah-langkah yang dilakukan saat pembelajaran berlangsung. Tahap ini merupakan tahapan inti dalam proses pembelajaran, guru menyajikan materi pelajaran yang telah disiapkan. Kegiatan yang dilakukan guru, antara lain:

1) Menjelaskan tujuan pengajaran siswa

2) Menuliskan pokok-pokok materi yang akan dibahas

3) Membahas pokok-pokok materi yang telas ditulis

4) Menggunakan alat peraga

5) Menyimpulkan hasil pembahasan dari semua pokok materi.

c. Tahap penilaian dan tindak lanjut (evaluasi), ialah penilaian atas hasil belajar siswa setelah mengikuti pembelajaran dan tindak lanjutnya. Setelah rnelalui tahap instruksional, langkah selanjutnya yang ditempuh guru adalah mengadakan penilaian keberhasilan belajar siswa dengan melakukan post test. Kegiatan-kegiatan yang dapat dilakukan guru dalam tahap in 1, antara lain ${ }^{3}$ :

1) Mengajukan pertanyaan pada siswatentang materi yang telah dibahas

2) Mengulas kembali materi yang belum dikuasai siswa.

3) Memberi tugas atau pekerjaan rumah pada siswa.

4) Menginformasikan pokok materi yang akan dibahas pada

3 Yatim Riyanto. 2008. Paradigma Pembelajaran. Surabaya. Hal: 90. 
pertemuan berikutnya.

Selanjutnya menurut Nazaruddin bahwa "proses pembelajaran efektif adalah proses pembelajaran yang dapat memberikan hasil belajar maksimal berupa penguasaan pengetahuan, kemampuan, sikap, dan keterampilan kepada peserta didik sesuai dengan tujuan pembelajaran yang ditetapkan" 4 .

Proses pembelajaran perlu dirancang dengan memanfaatkan teori-teori belajar dan pembelajaran sedemikian rupa sehingga seluruh potensi yang terkait dengan proses pembelajaran dapat didayagunakan secara optimal.

Dari analisa data di atas dapat diinterpretasikan bahwa langkah-langkah pembelajaran pendidikan agama Islam harus betul-betul direncanakan secara tepat guna. Karena untuk mewujudkan proses pembelajaran yang efektif, maka harus memperhatikan berbagai komponen yang saling terkait dan saling mempengaruhi diantaranya, kurikulum, guru, metode, alat, dan lain-lain.

\section{Langkah-langkah Pembelajaran Pendidikan Agama Islam Dalam Meningkatkan Kualitas Kepribadian Siswa Di MTs Negeri Probolinggo}

Implementasi atau pelaksanaan pembelajaran pendidikan agama Islam merupakan aplikasi dari langkah-langkah pembelajaran yang telah dibuat oleh guru sebelumnya.

Dari data lapangan menunjukkan bahwa implementasi atau pelaksanaan pembelajaran pendidikan agama Islam di MTs Negeri Probolinggo dari tahap persiapan, pelaksanaan, evaluasi, dan tindak lanjut dari proses pembelajaran. Pada tahap persiapan pembelajaran sudah baik yang mana pelaksanaannya dimulai dengan sholat dhuha berjamaah dan membaca tartil al-qur'an secara bersama-sama terlebih dahulu kemudian baru masuk kelas. Jadi, siswa MTs Negeri Probolinggo sebelum melaksanakan proses belajar mengajar siswa diajak sholat dhuha berjamaah dan membaca tartil al-qur'an terlebih dahulu.

Kegiatan sholat dhuha berjamaah dan membaca tartil al-qur'an ini dilakukan untuk melatih siswa MTs Negeri Probolinggo agar siswa mampu mempraktekkan dari isi materi pelajaran yang telah diterima, baru setelah itu melakukan appersepsi, pemberian motivasi kepada siswa, dan dilanjutkan dengan menyampaikan materi apa yang akan disampaikan sesuai dengan materi pokok yang akan diajarkan. Adakalanya sebelum pelajaran dimulai, dilakukan doa terlebih dahulu dengan bacaan al-fatihah dan dilanjutkan dengan memeriksa kehadiran siswa, kemudian menyampaikan materi pokok yang akan diajarkan. Menanyakan tentang materi pelajaran yang sudah

${ }^{4}$ Nazaruddin, Mgs. 2007. Manajemen Pembelajaran Implementasi Konsep. Karakteristik Dan Metodologi Pendidikan Agama Islam di Sekolah Umum. Yogyakarta. Hal:33 
diberikan pada pertemuan sebelunya, agar siswa tetap ingat pada materi yang sudah diajarkan sebelunya.

Kegiatan sholat dhuha berjamaah dan membaca tartil al-qur'an secara bersama-sama di MTs Negeri Probolinggo sudah dijadwalkan sebelum proses pembelajaran dilaksanakan yaitu kalau hari senin tidak ada kegiatan sholat dhuha berjamaah dan membaca tartil al-qur'an, karena hari senin itu waktunya digunakan untuk upacara bendera. Kalau hari selasa sampai hari kamis itu jadwalnya membaca tartil al-qur'an dan kalau hari jum'at jadwalnya sholat dhuha berjamaah dan membaca tartil al-qur'an dan khusus hari sabtu jadwalnya yasinan dan sabtu bersih.

Dari hasil lapangan tersebut dapat disimpulkan bahwa kegiatan persiapan pembelajaran pendidikan agama Islam di MTS Negeri Probolinggo cukup beragam kecuali kegiatan sholat dhuha berjamaah dan membaca tartil alqur'an secara bersama-sama yang memang sudah dijadwalkan. Hal ini menunjukkan bahwa kegiatan persiapan pembelajaran pendidikan agama Islam pada tiap guru tidak sama karena disesuaikan dengan kondisi dan tujuan dan materi pokok yang akan disampaikan, karena masing-masing guru sudah membuat RPP atau Rencana Pelaksanaan Pembelajaran.

Selanjutnya secara teori sebagaimana diungkapkan oleh Slameto, yaitu pada dasarnya tahap-tahap kegiatan pembelajaran mencakup persiapan, pelaksanaan, dan evaluasi. Strategi pembelajaran meliputi seluruli kegiatan atau tahapan-tahapan tersebut, tetapi titik beratnya berada di tahap persiapan",

Dari hasil data di atas dapat diinterpretasikan bahwa pada tahap kegiatan persiapan pembelajaran pendidikan agama Islam harus betul-betul direncanakan secara baik agar siswa merasa termotivasi dan bergairah dalam menerima pelajaran yang disampaikan dalam proses belajar mengajar di kelas.

Berkaitan dengan metode pembelajaran, yang mana salah satu alat pendidkan agama Islam ialah metode yang mana dengan menggunakan metode yang tepat maka ajaran-ajaran agama dapat diserap oleh anak didik dengan sebaik-baiknya. Metode yang tepat akan menentukan efektifitas dan efisiensi pembelajaran. Sebagai seorang guru pendidikan agama Islam maka perlu mengetahui metode-metode dalam pendidikan agama Islam.

Selanjutnya dalam pemilihan metode pembelajaran guru pendidikan agama Islam di MTs Negeri Probolinggo yaitu menggunakan metode ceramah, metode drill, tanya jawab, metode simulasi yang disesuaikan dengan materi dan kompetensi dasarnya. Selain itu bahwa penggunaan metode pembelajaran di MTs Negeri Probolinggo pada masing-masing guru

\footnotetext{
${ }^{5}$ Slameto, 1991. Proses Belajar Mengajar Dalam Sislem Kredif Semester. Jakarta. Hal: 26.
} 
pendidikan agama Islam tidaklah sama, akan tetapi disesuaikan dengan kondisi, materi dan kompetensi serta tujuan yang diharapkan yang akan disampaikan kepada siswanya.

Data lapangan tersebut kalau dihubungkan dengan terori yang ada sebagaimana dikatakan oleh Toto Suharto bahwa "Dalam pelaksanaan pembelajaran, pendidikan agama Islam memerlukan metode yang tepat menuju tujuan yang dicita-citakan. Bagaimanapun baik dan sempurnanya sebuah kurikulum, tidak berarti apa-apa jika tidak memiliki metode atau cara tepat dalam mentransformasikannya kepada peserta didik"6.

Dari hasil analisa di atas dapat diinterpretasikan bahwa ketidaktepatan dalam memilih metode secara praktis akan menghambat proses belajar mengajar, yang pada akhirnya berakibat terbuangnya waktu, dan tenaga yang percuma. Sementara itu, metode, materi, dan tujuan merupakan hal yang integral yang tidak bisa dipisahkan satu sama lain. Artinya, untuk menentukan sebuah metode, tergantung kepada materi dan tujuan yang diharapkan.

Untuk selanjutnya materi pelajaran, juga berperan penting dalam proses pembelajaran. Tanpa materi, suatu pembelajaran tidak dapat mencapai tujuan yang ditetapkan. Media pendidikan agama Islam adalah segala sesuatu yang dapat digunakan untuk menyalurkan pesan pendidikan agama Islam dari pengirim pesan atau guru kepada penerima (siswa) dan dapat merangsang pikiran, perasaan, perhatian, dan minat serta perhatian siswa sehingga terjadi proses belajar mengajar.

Azhar Arsyad "mengatakan bahwa media apabila dipahami secara garis besar adalah manusia, materi, atau kejadian yang membangun kondisi yang membuat siswa mampu memperoleh pengetahuan, ketrampilan, atau sikap"

Adapun media atau sumber belajar yang digunakan dalam menunjang proses pembelajaran pendidikan agama Islam di MTs Negeri Probolinggo adalah sebagai berikut: "Sumber belajar dalam pembelajaran pendidikan agama Islam diantaranya buku materi pendidikan agama Islam sesuai dengan kurikulum yang berlaku, LKS serta pendukung lain yang relevan. Adapun buku yang harus dimiliki siswa adalah buku LKS, sedangkan buku materi atau buku paket sudah disediakan di perpustakaan

Dari hasil analisa di atas dapat diinterpretasikan bahwa dalam proses belajar mengajar, media dan metode merupakan dua komponen yang saling berkaitan. Pemilihan salah satu metode mengajar tertentu akan mempengaruhi jenis media pengajaran yang sesuai, meskipun ada aspek lain yang harus diperhatikan dalam pemilihan media pembelajaran.

${ }^{6}$ Suharto, Toto 2006. Filsafat Pendidikan Islam. Jogjakarta. Hal: 137

${ }^{7}$ Arsyad, Azhar. 2003. Media Pembelajaran. Jakarta. Hal:3 
Untuk mengetahui sejauh mana keberhasilan dalam mencapai tujuan pembelajaran, maka diperlukan adanya evaluasi. Adapun hasil lapangan menunjukkan bahwa evaluasi yang dilakukan oleh guru pendidikan agama Islam di MTs Negeri Probolinggo mencakup tiga aspek yang dijadikan bahan evaluasi didalam pembelajaran pendidikan agama Islam, yang pertama aspek kognitif, biasanya evaluasinya dilakukan dengan cara tes tulis atau lisan, yang kedua yaitu aspek afektif, evaluasinya dilakukan dengan pengamatan tingkah laku atau sikap keseharian atau minat belajar siswa sedangkan aspek psikomotorik, hal ini bisa dilihat dari hasil praktek sholat atau baca AlQur'an.

Kemudian evaluasi juga dilakukan pada setiap semester ada ulangan harian dan ulangan blok (terdiri dari beberapa pokok). Kalau ulangan harian setiap kompetensi dasar, dan juga diadakan ulangan akhir semester ulangan blok akhir bersama, tiap menjelang akhir semester atau kenaikan atau ulangan akhir blok.

Selanjutnya dalam evaluasi yang berkaitan dengan kenaikan kelas di MTs Negeri Probolinggo sudah menentukan patokannya yaitu dengan adanya kriteria kenaikan kelas yaitu: Pertama, nilai semua mata pelajaran mencapai standart ketuntasan minimal (SKM). Kalau pada masing-masing mata pelajaran pendidikan agama islam yaitu nilai SKM nya: 75 pada mata pelajaran Al-Qur'an Hadits, Aqidah Akhlak, Fiqih dan Sejarah Kebudayaan Islam sedangkan untuk mata pelajaran Bahasa Arab standart ketuntasan minimalnya adalah 70. Kedua, lancar baca tulis al-qur'an. Keempat, memiliki nilai kepribadian (kelakuan, kerajinan dan kerapian) sekurang-kurangnya pada kategori cukup. Kelima, kehadiran siswa dalam satu tahun pelajaran tidak kurang dari 95\% atau alpa sebanyak-banyaknya 12 hari.

Evaluasi dalam pendidikan agama Islam merupakan "cara atau teknik penilaian terhadap tingkah laku manusia didik berdasarkan standar perhitungan yang bersifat komperhensif dari seluruh aspek-aspek kehidupan mental psikologis dan spiritual relegius" ${ }^{8}$.

Seperti yang telah dijelaskan oleh Muhaimin bahwa, upaya peningkatan kualitas pembelajaran pendidikan agama Islam di sekolah dapat dilakukan dengan memberikan perhatian penuh terhadap berbagai komponen-komponen yang ada dalam pembelajaran Pendidikan Agama Islam itu sendiri, yang meliputi komponen perencanaan, komponen sarana dan prasarana, komponen guru, komponen kelas dan lain-lain.

Dari hasil analisa di atas dapat diinterpretasikan bahwa evaluasi dalam Proses belajar mengajar merupakan suatu sistem yang terdiri atas beberapa

\footnotetext{
${ }^{8}$ Uhbiyati, Nur. 1999. Ilmu Pendidikan Islam. Bandung: Hal: 144
} 
komponen yang saling berkaitan dan saling berinteraksi dalam mencapai tujuan. Salah satu komponen tersebut adalah evaluasi. Evaluasi pembelajaran memiliki peranan yang sangat penting karena evaluasi hasil belajar yang dicapai siswa akan dapat diketahui setelah menyelesaikan dalam kurun waktu tertentu, ketepatan metode mengajar yang digunakan dalam penyajian pelajaran serta tercapai atau tidaknya tujuan instruksional yang dirumuskan. Dengan demikian, evaluasi berfungsi pula sebagai feed back dalam rangka memperbaiki proses belajar mengajar yang telah dilaksanakan guru guna melakukan pembenahan terhadap kualitas kepribadian siswa.

\section{Kesimpulan}

Berdasarkan hasil penelitian yang dilakukan dapat disimpulkan sebagai berikut:

1. Langkah-langkah pembelajaran pendidikan agama Islam dalam meningkatkan kualitas kepribadian siswa di MTs Negeri Probolinggo bisa dikatakan cukup baik. Kaitannya dengan guru khususnya guru bidang studi pendidikan agama Islam di MTs Negeri Probolinggo telah melakukan langkah-langkah pembelajaran melalui Musyawarah Guru Mata Pelajaran pendidikan agama Islam (MGMP), mulai dari hal penyusunan silabus yang sesuai standart isi, standart kompetensi lulusan dan panduan penyusunan KTSP; membuat analisis hari efektif; analisis pekan efektif; program tahunan; program semester dan penyusunan rencana pelaksanaan pembelajaran (RPP).

2. Implementasi pembelajaran pendidikan agama Islam dalam meningkatkan kualitas kepribadian siswa di MTs Negeri Probolinggo ialah dimulai dari tahap persiapan, pelaksanaan, evaluasi.

a. Pada tahap persiapan pembelajaran sudah baik yang mana pelaksanaannya dimulai dengan sholat dhuha berjamaah dan membaca tartil al-qur'an secara bersama-sama terlebih dahulu kemudian baru masuk kelas. Kegiatan persiapan pembelajaran pendidikan agama Islam pada tiap guru tidak sama karena disesuaikan dengan kondisi dan tujuan dan materi pokok yang akan disampaikan, karena masingmasing guru sudah memiliki Rencana Pelaksanaan Pembelajaran masing-masing, kecuali kegiatan sholat dhuha berjamaah dan membaca tartil al-qur'an secara bersama-sama yang memang sudah dijadwalkan.

b. Penggunaan metode pembelajaran di MTs Negeri Probolinggo pada masing-masing guru pendidikan agama Islam tidaklah sama, akan tetapi disesuaikan dengan kondisi, materi dan kompetensi serta tujuan yang diharapkan yang akan disampaikan kepada siswanya. 
c. Media atau sumber belajar dalam pembelajaran pendidikan agama Islam diantaranya buku materi pendidikan agama Islam sesuai dengan kurikulum yang berlaku, LKS serta pendukung lain yang relevan.

d. Dalam evaluasi yang berkaitan dengan kenaikan kelas di MTs Negeri Probolinggo sudah menentukan patokannya yaitu dengan adanya kriteria kenaikan kelas yaitu: Pertama, nilai semua mata pelajaran mencapai standart ketuntasan minimal (SKM). Kedua, lancar baca tulis al-qur'an. Ketiga, memiliki nilai kepribadian (kelakuan, kerajinan dan kerapian) sekurang-kurangnya pada kategori cukup. Keempat, kehadiran siswa dalam satu tahun pelajaran tidak kurang dari $95 \%$ atau alpa sebanyak-banyaknya 12 hari. 


\section{Daftar Pustaka}

Arifi, Ahmad. 2009. Politik Pendidikan Agama Islam Menelusuri Ideologi dan Aktualisasi Pendidikan Islam di Tengah Arus Globalisasi. Yogyakarta: Teras.

Arifin, Muzayyin, 2000. Filsafat Pendidikan Islam. Jakarta: Bumi Aksara.

Arsyad, Azhar. 2003. Media Pembelajaran. Jakarta: PT Raja Grafindo Persada.

Azra, Azyumardi. 2000. Pendidikan Islam; Tradisi dan Modernisasi Menuju MileniumBaru. Jakarta: Logos Wacana Ilmu.

Daradjat, Zakiah. 1996. Ilmu Pendidikan Islam. Jakarta: Bumi Aksara.

Depag RI. 1996. Al-Qur'an dan Terjemahannya Departemen Agama Republik Indonesia. Semarang: PT Karya Toha Putra.

Depdikbud. 1999. Kamus Besar Bahasa Indonesia. Jakarta: Balai Pustaka.

Depdikbud, 1995. Peraturan Pelaksanaan Sistem Pendidikan Nasional. Jakarta Armas Duta Jaya.

Depdiknas, 2004. Kurikulum Berbasis Kompetensi Pendidikan Agama Islam. Jakarta: Balai Pustaka.

Djumransjah, 2007. Pendidikan Islam Menggali Tradisi. Mengukuhkan Eksistensi, Malang: UIN-Malang Press.

Djamarah, Saiful Bahri. 2002. Psikologi Belajar. Jakarta: PT. Reneka Cipta

Fatimah, Enung. 2006. Psikologi Perkembangan (Perkembangan Peserta Didik). Bandung: CV. Pustaka Setia.

Hamalik, Oemar. 1991. Strategi Belajar Mengajar. Bandung: CV Sinar Baru.

Hasbullah, 2003. Dasar-Dasar Ilmu Pendidikan. Jakarta: PT. Raja Grafindo Persada

Husniyah, Fatmawati. 2009. Pelaksanaan Pembelajaran Pendidikan Agama Islam Dalam Membentuk Kepribadian Muslim Di SMP Negeri 13 Malang, Skripsi tidak diterbitkan. Malang: Universitas Negeri Malang.

Ihsan, Hamdani, 2007. Filsafat Pendidikan Islam. Bandung: CV Pustaka Setia. 
Jalaluddin. 2003. Filsafat Pendidikan Islam. Jakarta: Raja Grafindo Persada.

Jalaluddin. 2007. Psikologi Agama. Jakarta: Raja Grafindo Persada.

Jalaluddin, Abdur Rahman bin Abi Bakar al-Suyuthi Imam. 1966. al-Jami’ alShaghir. Darul Qalam.

Langgulung, Hasan. 1995. Beberapa Pemikiran tentang Pendidikan Islam. Bandung: Al-Ma'arif.

Ma'arif, Syamsul. 2007. Revitalisasi Pendidikan Islam. Yogyakarta: Graha Ilmu.

Majid, Abdul. 2007. Perencanaan Pembelajaran Mengembangkan Standar Kompetensi Guru. Bandung: PT. Remaja Rosdakarya.

Majid, Abdul. 2005. Pendidikan Agama Islam Berbasis Kompetensi. Bandung: Remaja Rosdakarya.

Margono, S. 2005. Metodologi Penelitian Pendidikan. Jakarta: PT Rineka Cipta.

Maunah, Binti. 2009. Ilmu Pendidikan. Yogyakarta: Teras.

Moleong, Lexy. J. 2010. Metodologi Penelitian Kualitatif. Bandung: Remaja Rosda Karya Offset.

Muhaimin, 1996. Strategi Belajar Mengajar. Surabaya. Citra Media.

Muhaimin dan Abdul Mujib. 1993. Pemikiran Pendidikan Islam; Kajian Filosofis dan Kerangka Dasar Operasionalisasinya. Bandung: Tri Genda Karya.

Mulyasa, 2004. Pendidikan Agama Islam Berbasis Kompetensi. Bandung: PT. Rosda Karya.

Naim, Ngainun. 2009. Rekonstruksi Pendidikan Nasional Membangun Paradigma yang Mencerahkan. Yogyakarta: Teras.

Nazaruddin, Mgs. 2007. Manajemen Pembelajaran Implementasi Konsep. Karakteristik Dan Metodologi Pendidikan Agama Islam di Sekolah Umum. Yogyakarta: Teras.

Partanto, A. Pius. 1994. Kamus Ilmiah Populer. Surabaya: Arkola. 
Prasasti, Pipin Puri. 2007. Strategi guru agama Islam dalam pembinaan Akhlakul karimah siswa MTs. Hidayatus Salihin Turus Gurah Kediri, Skripsi tidak diterbitkan. Malang: Universitas Islam Negeri Malang.

Program Pascasarjana STAIN Probolinggo. 2011. Pedoman Penulisan Karya Ilmiah Program Pascasarjana STAIN Probolinggo. Probolinggo: STAIN Probolinggo.

Suharto, Toto 2006. Filsafat Pendidikan Islam. Jogjakarta: Ar-Ruzz Media.

Sujanto, Agus dkk. 2008. Psikologi Kepribadian. Jakarta: PT Bumi Aksara.

Sugiyono. 2008. Metode Penelitian Kuantitatif Dan Kualitatif Dan Reseach dan Development. Bandung: Alfabeta.

Uhbiyati, Nur. 1999. Ilmu Pendidikan Islam. Bandung: Pustaka Setia. 